\title{
Development of Color-Based Extraction Methods for Nutritional Quality Grouping of Chicken Eggs
}

\author{
Juli Yanto, Sarifuddin Madenda, Lussiana ETP
}

\begin{abstract}
Food ingredients are very important to maintain human survival, because the human body needs energy used for daily activities. Eggs are one of the nutritional intake in this case is a protein that is often consumed by the community, especially the number of available chicken eggs. The nutritional content in all parts of the egg has benefits that are very beneficial for the human body. In an egg, the level of protein needed by the body is as much as $10.8 \%$ in egg whites and $16.3 \%$ in egg yolks. The quality of eggs is determined by the intensity of the yolk. The color of the yolk is the main characteristic of egg quality. There are 3 kinds of egg yolks that are found. Pale yellow, ordinary yellow and orange yellow. Egg yolks are rich in vitamins and minerals, especially vitamin A, vitamin B2, folic acid, vitamin B6, and vitamin B12, iron, calcium, phosphorus, potassium and cholesterol. done by acquiring the image of the egg yolk using the object image of egg yolk as much as 30 grains, then the preprocessing process with a background image then uniformizing the size and then grouping the characteristics based on the color so that the nutritional content can be classified and the extras are classified using matlab based on sample testing in the BPPT Laboratory examiner of the Biotechnology Institute then the Technology Assessment and Application Agency to determine the nutrient content based on the color of the yolk with the similarity in color values with the Ecluiden Distance method Development of feature extraction on chicken egg yolks based on digital images and application for grouping Nutritional content of chicken eggs based on chicken egg yolk extraction features produce $85 \%$ similarity in yellow.
\end{abstract}

Index Terms: Egg yolk, Euclidean Distance, Feature extraction

\section{INTRODUCTION}

Egg quality is determined by the intensity of egg yolk. The color of the yolk is the main characteristic of egg quality (Chung 2002). The color of the yolk affects the tastes of consumers, generally the preferred ones range from yellow gold to orange, there are 3 kinds of yolk colors that are found. Pale yellow, slightly orange yellow and dark orange.

Revised Manuscript Received on April 25, 2019.

Juli Yanto, Technology Information, Sekolah Tinggi Teknoligi Informasi, 12410, Indonesia.

Sarifuddin Madenda, Technology Information, gunadarm University, 16424, Indonesia.

Lussiana ETP, Technology Information, Sekolah Tinggi Manajemen Informatika dan Komputer STIK Jakarta , 12140, Indonesia.
Visually evaluating the yolk color with the usual La Roche scale, the most intensive color is found in bio eggs, on the contrary, the most intensive color is found in some special varieties of eggs, such as extra egg yolks or free range farmer eggs[1]. Egg yolks vary between 4-13 values from the La Roche scale. This method is widely spread in general practice as a simple method for assessing the quality of egg yolks. The marked difference is in the preference of hue color egg yolks among consumers in various European countries. Consumers in Germany, the Netherlands, Spain and Belgium prefer yellow with 13-14 values from the La Roche scale, in France, southern England, and Finland with a score of 11-12 from the La Roche scale, and in Ireland, northern England, and Sweden with a score of 8-9 from the La Roche scale [2].

Feature extraction is the process of indexing an image database and its contents. Mathematically, each feature extraction is an econde of vector $\mathrm{n}$ dimensions which are called feature vectors. The feature vector component is calculated by image processing and analysis techniques and is used to compare one citar with its original citar. Feature extraction is clarified into 3 types, namely low-level, middle-level and high-level. Low-level feature is feature extraction based on visual contents such as color and texture, middle-level feature is extraction based on image area determined by segmentation, while high-level feature is feature extraction based on semantic information contained in the image [3].

The color space HCL (Hue, Chroma, Luminance) was developed based on the results of the analysis of four color spaces namely HSL, HSV and $\mathrm{L} * \mathrm{a} * \mathrm{~b} *$ or $\mathrm{L} * \mathrm{C} * \mathrm{H} *$. This color space combines the advantages that exist in each color space. Thus a more uniform color space will be produced against human visual perception

\section{RESEARCH METHOD}

The stages of the research that will be carried out acquire the image of the egg yolk using the object image of egg yolk as much as 30 items, then the preprocessing process with the background image and the image obtained is normalized the color component and then uniformized the size then grouped the characteristics based on the color so it can be known the nutritional content based on the sample test in BPPT Lab Testing Laboratory Biotechnology Hall Technology Assessment and Application Agency then to determine the nutritional content based on the color of the yolk with similarity in color values with the

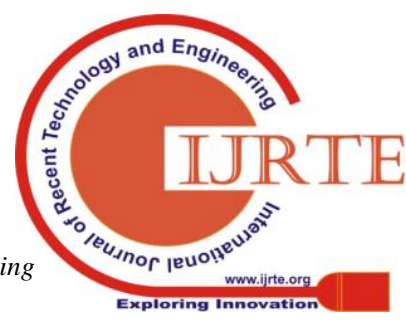


Ecluide Distance method as shown in Fig.1.

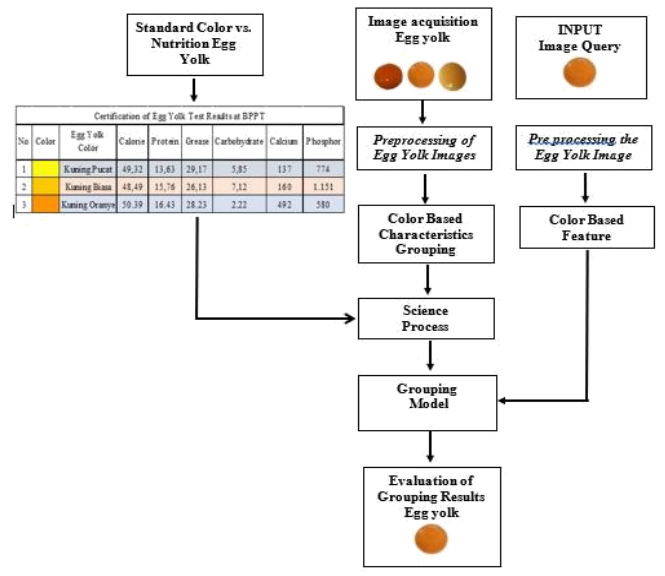

Fig. 1 Research Steps

In image color segmentation, the main process is to determine which pixels are included in the same segment and determine the boundary between two segments that have different color maps. To do this, it is necessary to measure the difference in distance between the two colors. There are several color distance formulas that have been developed by researchers with reference to the 3 -D color coordinate model used.

For color space in the 3-D Cartesian background, the color distance between two pixels can be calculated using the Euclidean distance formula or city block distance (also called Manhatatn distance) where (X1, Y1,) and (X2, Y2) respectively is the color component of the first pixel and the second pixel.

\section{RESULTS AND DISCUSSION}

\section{A. Image Acquisition}

The acquisition process uses object images of egg yolk as much as 30 items, the picture of the domestic chicken egg yolk is broken so that it looks the appearance of the yolk which is then imaged using a mobile camera with a qualification of 13 mega pixels (41 $28 \times 3096)$ with $1920 \mathrm{x}$ 1080 resolution, shooting position from on. Then the egg image is matched with yolk color fan, where there are 3 qualities of egg yolk. The quality of egg yolks consists of 15 samples for each grade, namely:

1. Orange Yellow Egg Grade (color 11-15) on Yolk Color Fan

2. Ordinary Egg Yolk Grade (color 6-10) on Yolk Color Fan

3. Pale Egg Yolk Grade (1-5 colors) on Yolk Color Fan

There is also the Image Acquisition Result as shown in Figure 2.

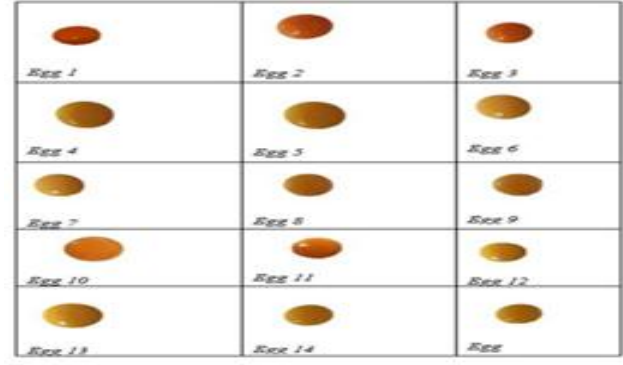

Fig. 2 Results of Image Acquisition

\section{B. Reprosecing Image of Egg Yolk}

The background image and the image obtained are normalized by the Color component. Normalization is carried out to improve the accuracy of the image reduction process. To get a better image, before making a reduction for each image and background, the color component normalization process is carried out. Color color component Egg yolks are taken from each pixel in the image. The example of the image segmentation results is shown in Fig. 3.

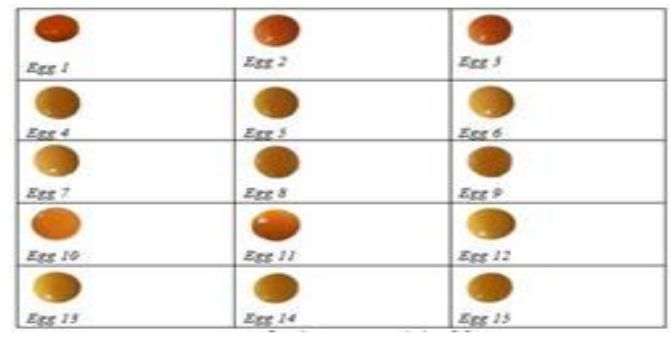

Fig. 3 Image segmentation image 4.3

Determine the Extremation of the Egg Yolk Image Characteristics Based on the results of the Extras in the characteristics of the Egg Yolk Image using the mat shown in Table 1.

\section{Evaluation of Egg Yolk Grouping Results}

Table 1 Results of chroma Luminance yolk

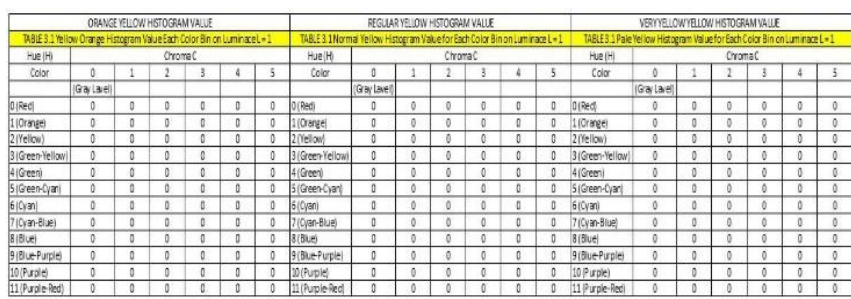

From the orange yellow L1 analysis above it can be concluded that each value of Hue $(\mathrm{H})$ is 0 . So there is no difference from each Hue $(\mathrm{H})$ or no color dominates. So the comparison of the usual yellow L1 results above is equal to produce 0 Luminance. So, from the pale yellow L1 analysis it can be concluded that each Hue color does not have a difference, the number is equal to 0 .

Table 2 Results of chroma Luminance yolk image analysis with segmentation 


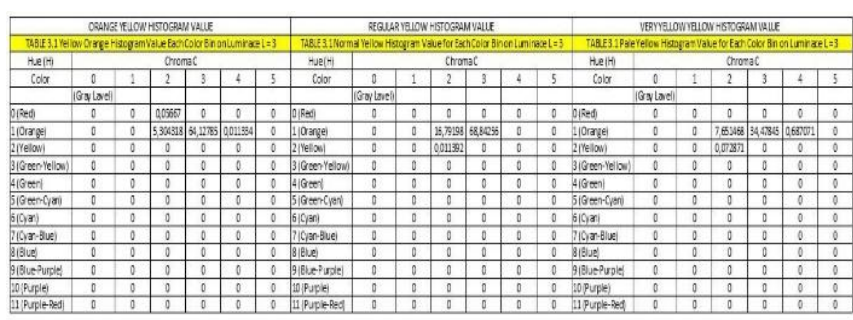
concluded that the dominating value of Hue $(\mathrm{H})$ is the orange Hue $(\mathrm{H})$ value which is 0.408024481 . So from the L2 yellow orange the dominating color is orange. We can see in the usual yellow L2 table above that the value of Hue $(\mathrm{H})$ Orange produces Luminance with a value of 0.318979266 and other Luminance value of 0 , then the total Luminance L2 amounts to 0.318979266 . From the Pale Yellow L2 analysis above it can be concluded that the more dominating value is Hue (orange) which is 2.95648553 and the other is the same which has a value of 0 .

Table 3 Results of chroma Luminance yolk image analysis with segmentation

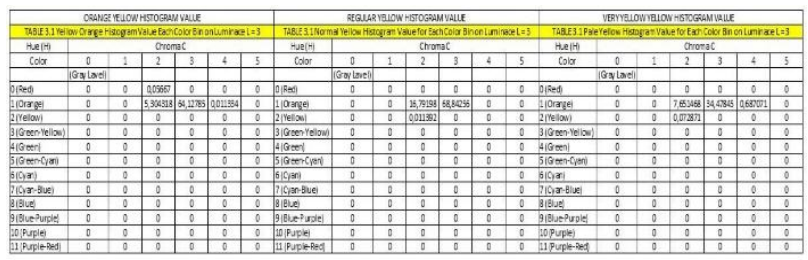

From the orange yellow L3 analysis above, it can be concluded that the value of red Hue $(\mathrm{H})$ is 0.056670067 and orange Hue $(\mathrm{H})$ is 69.44349994 . Therefore, the dominating color of orange L3 is red and orange with 69,50017001. We can see in the usual yellow L3 table above that the value of Orange Hue $(\mathrm{H})$ produces Luminance with a value of 85.6345309 and the value of Yellow Hue $(\mathrm{H})$ produces Luminance with a value of 0.011392117 . The other luminance is 0 , the total Luminance L3 is 85,64593301 . From the pale yellow L3 analysis above it can be concluded that there are 2 dominating values, namely Hue (red) and Hue (orange) Hue Luminance (red) values are 0.056670067 and Hue (orange) are 69.44349994.

Table 4 Results of chroma Luminance yolk image analysis with segmentation

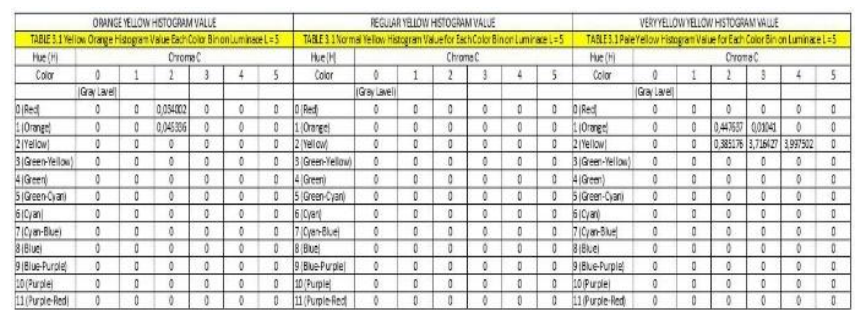

From the orange yellow L5 data analysis above it can be taken that the red Hue $(\mathrm{H})$ has a value of 0.03400204 and an orange Hue $(\mathrm{H})$ 0.045336053. Therefore, the dominating color of the orange yellow L5 is red and orange with the number 0.079338094 . So the comparison of the usual yellow L5 results above is equally yielding 0 Luminance.
From the orange yellow L2 analysis above, it can be

From the pale yellow L3 analysis above, it can be concluded that there are 2 dominating values, namely Hue (red) and Hue (orange) Luminance Hue (red) is 0.03400204 and Hue (orange) is 0.045336053 .

From the orange yellow L4 analysis above, it can be concluded that each value of Hue $(\mathrm{H})$ is 0 . So there is no difference from each Hue $(\mathrm{H})$ or no color dominates. We can see in the usual yellow L4 table above that the value of Orange Hue $(\mathrm{H})$ produces Luminance with a value of 13.88938232 and the value of Yellow Hue $(\mathrm{H})$ produces Luminance with a value of 0.0125313283 . The other luminance is 0, the total Luminance L4 is 14.0236956 . From the pale yellow L4 analysis above that orange hue has a value of 27.4932334 and yellow hue is 18.09285863 . Therefore the dominating color is the color of orange and yellow hue.

Table 5 Results of chroma Luminance yolk image analysis with segmentation

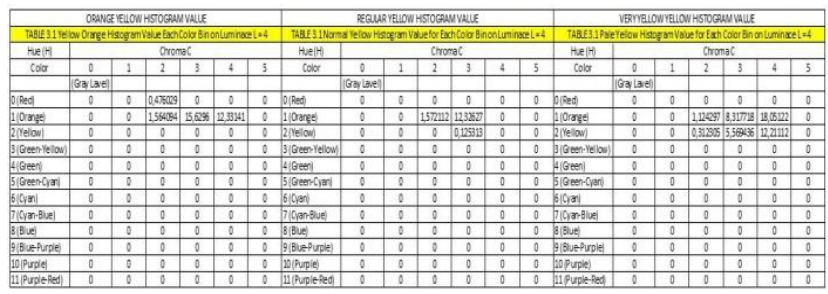

\section{Grouping of Egg Yolk Nutritional Value}

At this stage it is carried out by measuring the similarity of the extraction characteristics of the image of the egg yolk which is tested by the extraction value of the egg yolk data contained in the database. The method used is the Ecluide Distance method with the following equation:

Euclidean formula

$\left.\mathrm{d}=\left(\left(\mathrm{x}_{1}-\mathrm{x}_{2}\right)^{2}\right)+\left(\mathrm{y}_{1}-\mathrm{y}_{2}\right)^{2}\right)^{1 / 2}$

\section{E. The Science Process}

To obtain data on the value of giji from egg yolks. Tests have been carried out at the BPPT Lab Testing Laboratory of the Biotechnology Office of the Agency for the Assessment and Application of Technology.

Table 6 sample with each color

\begin{tabular}{|l|c|c|c|}
\hline \multicolumn{4}{|c|}{ Egg Yolk Testing Sample } \\
\hline \multicolumn{1}{|c|}{ Information } & Bottle Weight & Number of Egg Yolks & Species of Egg Yolk \\
\hline Pale yolk & $10,38 \mathrm{Gram}$ & 3 Egg yolks & $170 \mathrm{Gram}$ \\
\hline Ordinary egg yolks & $10,43 \mathrm{Gram}$ & 3 Egg yolks & $166 \mathrm{Gram}$ \\
\hline Orange yolk & $10,64 \mathrm{Gram}$ & 3 Egg yolks & $168 \mathrm{Gram}$ \\
\hline
\end{tabular}

Furthermore, the value of Color and the content of the giji value of each egg yolk image are shown in Table 7.

Table 7 The nutritional value of the yolk is based on the color value of the yolk image

Published By: 


\section{Development of Color-Based Extraction Methods for Nutritional Quality Grouping of Chicken Eggs}

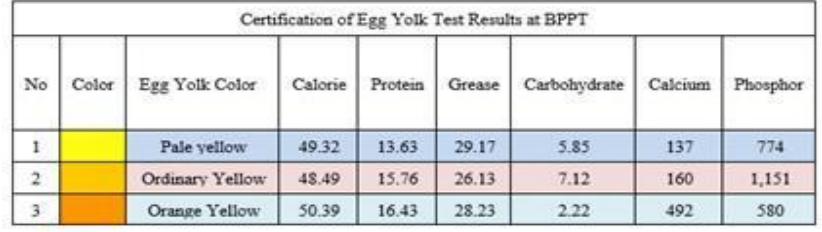

A search method for proximity values of 2 variables, besides being easy, this method does not take time, and is a fast process. Euclidean is a heuristic function which is obtained based on the direct barrier free distance such as to get the value of the diagonal line length in the triangle.

But before getting the results both points must be represented in 2-dimensional coordinates $(\mathrm{x}, \mathrm{y})$. Two points $\mathrm{p} 1=(\mathrm{x} 1, \mathrm{y} 1)$ and $\mathrm{p} 2=(\mathrm{x} 2, \mathrm{y} 2)$.

\section{F. Evaluation of Egg Yolk Grouping Results}

At this stage two experiments were carried out with the trial with the image of the yolk without segmentation and the Trial with Image Yolk segmentation results to see the distance of the egg yolk similarity.

Table 8 Chroma Luminance Analysis results with segmentation

\begin{tabular}{|l|c|c|c|}
\hline \multicolumn{1}{|c|}{ Color } & Yellow Orange & Ordinary Yellow & Pale Yellow \\
\hline \multicolumn{1}{|c|}{ Hue $(\mathrm{H})$} & $\mathrm{L}=1$ & $\mathrm{~L}=1$ & $\mathrm{~L}=1$ \\
\hline 0 (Red) & 0 & 0 & 0 \\
\hline 1 (Orange) & 0 & 0 & 0 \\
\hline 2 (Yellow) & 0 & 0 & 0 \\
\hline 3 (Green-Yellow) & 0 & 0 & 0 \\
\hline 4 (Green) & 0 & 0 & 0 \\
\hline 5 (Green-Cyan) & 0 & 0 & 0 \\
\hline 6 (Cyan) & 0 & 0 & 0 \\
\hline 7 (Cyan-Blue) & 0 & 0 & 0 \\
\hline 8 (Blue) & 0 & 0 & 0 \\
\hline 9 (Blue-Purple) & 0 & 0 & 0 \\
\hline 10 (Purple) & 0 & 0 & 0 \\
\hline 11 (Purple-Red) & 0 & 0 & 0 \\
\hline & 0 & 0 & 0 \\
\hline
\end{tabular}

From the orange yellow L1 analysis above it can be concluded that each value of Hue $(\mathrm{H})$ is 0 . So there is no difference from each Hue $(\mathrm{H})$ or no color dominates. So the comparison of the usual yellow L1 results above is equal to produce 0 Luminance. So, from the pale yellow L1 analysis it can be concluded that each Hue color does not have a difference, the number is equal to.

Table 9 Chroma Luminance Analysis results with segmentation

\begin{tabular}{|l|c|c|c|}
\hline \multicolumn{1}{|c|}{ Color } & Yellow Orange & Ordinary Yellow & Pale Yellow \\
\hline \multicolumn{1}{|c|}{ Hue $(\mathrm{H})$} & $\mathrm{L}=2$ & $\mathrm{~L}=2$ & $\mathrm{~L}=2$ \\
\hline 0 (Red) & 0 & 0 & 0 \\
\hline 1 (Orange) & 0,148117185 & 0,509066533 & 0,897721869 \\
\hline 2 (Yellow) & 0 & 0 & 0 \\
\hline 3 (Green-Yellow) & 0 & 0 & 0 \\
\hline 4 (Green) & 0 & 0 & 0 \\
\hline 5 (Green-Cyan) & 0 & 0 & 0 \\
\hline 6 (Cyan) & 0 & 0 & 0 \\
\hline 7 (Cyan-Blue) & 0 & 0 & 0 \\
\hline 8 (Blue) & 0 & 0 & 0 \\
\hline 9 (Blue-Purple) & 0 & 0 & 0 \\
\hline 10 (Purple) & 0 & 0 & 0 \\
\hline 11 (Purple-Red) & 0 & 0 & 0 \\
\hline Total & 0,148117185 & 0,509066533 & 0,897721869 \\
\hline
\end{tabular}

From the orange yellow L2 analysis above, it can be concluded that the dominating value of Hue $(\mathrm{H})$ is the orange Hue $(\mathrm{H})$ value which is 0.408024481 . So from the L2 yellow orange the dominating color is orange. We can see in the usual yellow L2 table above that the value of Hue (H) Orange produces Luminance with a value of 0.318979266 and other Luminance value of 0 , then the total Luminance L2 amounts to 0.318979266. From the Pale Yellow L2 analysis above it can be concluded that the more dominating value is Hue (orange) which is 2.95648553 and the other is the same which has a value of 0.

Table 9 Chroma Luminance Analysis results with segmentation

\begin{tabular}{|c|c|c|c|}
\hline Color & Yellow Orange & Ordinary Yellow & Pale Yellow \\
\hline Hue $(\mathrm{H})$ & $\mathrm{L}=3$ & $\mathrm{~L}=3$ & $\mathrm{~L}=3$ \\
\hline 0 (Red) & 0,036442584 & 0,000269368 & 0 \\
\hline 1 (Orange) & 64,48663558 & 95,02854913 & 53,66921838 \\
\hline 2 (Yellow) & 0 & 0 & 0,006627292 \\
\hline 3 (Green-Yellow) & 0 & 0 & 0 \\
\hline 4 (Green) & 0 & 0 & 0 \\
\hline 5 (Green-Cyan) & 0 & 0 & 0 \\
\hline $6($ Cyan) & 0 & 0 & 0 \\
\hline 7 (Cyan-Blue) & 0 & 0 & 0 \\
\hline 8 (Blue) & 0 & 0 & 0 \\
\hline 9 (Blue-Purple) & 0 & 0 & 0 \\
\hline 10 (Purple) & 0 & 0 & 0 \\
\hline 11 (Purple-Red) & 0 & 0 & 0 \\
\hline Total & 64,52307816 & 95,0288185 & 53,67584567 \\
\hline
\end{tabular}

From the orange yellow L3 analysis above, it can be concluded that the value of red Hue $(\mathrm{H})$ is 0.056670067 and orange Hue $(\mathrm{H})$ is 69.44349994 . Therefore, the dominating color of orange L3 is red and orange with 69.50017001. We can see in the usual yellow L3 table above that the value of Orange Hue $(\mathrm{H})$ produces Luminance with a value of 85.6345309 and the value of Yellow Hue $(\mathrm{H})$ produces Luminance with a value of 0.011392117 . The other luminance is 0 , the total Luminance L3 is 85.64593301 . From the pale yellow L3 analysis above it can be concluded that there are 2 dominating values, name-ly Hue (red) and Hue (orange) Hue Luminance (red) values are 0.056670067 and Hue (orange) are 69.44349994.

Table 10 Chroma Luminance Analysis results with segmenta-tion

\begin{tabular}{|l|c|c|c|}
\hline \multicolumn{1}{|c|}{ Color } & Yellow Orange & Ordinary Yellow & Pale Yellow \\
\hline \multicolumn{1}{|c|}{ Hue $(\mathrm{H})$} & $\mathrm{L}=4$ & $\mathrm{~L}=4$ & $\mathrm{~L}=4$ \\
\hline 0 (Red) & 0 & 0 & 0 \\
\hline 1 (Orange) & 0 & 4,450416712 & 44,16976298 \\
\hline 2 (Yellow) & 0 & 0 & 0,166081154 \\
\hline 3 (Green-Yellow) & 0 & 0 & 0 \\
\hline 4 (Green) & 0 & 0 & 0 \\
\hline 5 (Green-Cyan) & 0 & 0 & 0 \\
\hline 6 (Cyan) & 0 & 0 & 0 \\
\hline 7 (Cyan-Blue) & 0 & 0 & 0 \\
\hline 8 (Blue) & 0 & 0 & 0 \\
\hline 9 (Blue-Purple) & 0 & 0 & 0 \\
\hline 10 (Purple) & 0 & 0 & 0 \\
\hline 11 (Purple-Red) & 0 & 0 & 0 \\
\hline \multicolumn{1}{|c|}{ Total } & 0 & 4,450416712 & 44,33584414 \\
\hline
\end{tabular}

From the orange yellow L4 analysis above, it can be concluded that each value of Hue $(\mathrm{H})$ is 0 . So there is no difference from each Hue $(\mathrm{H})$ or no color dominates.

Published By:

Blue Eyes Intelligence Engineering \& Sciences Publication 
We can see in the usual yellow L4 table above that the value of Orange Hue $(\mathrm{H})$ produces Luminance with a value of 13.88938232 and the value of Yellow Hue $(\mathrm{H})$ produces Luminance with a value of 0.0125313283 . The other luminance is 0 , the total Luminance L4 is 14.0236956 . From the pale yellow L4 analysis above that orange hue has a value of 27.4932334 and yellow hue is 18.09285863 . Therefore the dominating color is the color of orange and yellow hue.

Table 11 Chroma Luminance Analysis results with segmentation

\begin{tabular}{|l|c|c|c|}
\hline \multicolumn{1}{|c|}{ Color } & Yellow Orange & Ordinary Yellow & Pale Yellow \\
\hline Hue $(\mathrm{H})$ & $\mathrm{L}=5$ & $\mathrm{~L}=5$ & $\mathrm{~L}=5$ \\
\hline 0 (Red) & 0,076604702 & 0 & 0 \\
\hline 1 (Orange) & 0,416322204 & 0,011659775 & 1,084390581 \\
\hline 2 (Yellow) & 0 & 0 & 0,006167063 \\
\hline 3 (Green-Yellow) & 0 & 0 & 0 \\
\hline 4 (Green) & 0 & 0 & 0 \\
\hline 5 (Green-Cyan) & 0 & 0 & 0 \\
\hline 6 (Cyan) & 0 & 0 & 0 \\
\hline 7 (Cyan-Blue) & 0 & 0 & 0 \\
\hline 8 (Blue) & 0 & 0 & 0 \\
\hline 9 (Blue-Purple) & 0 & 0 & 0 \\
\hline 10 (Purple) & 0 & 0 & 0 \\
\hline 11 (Purple-Red) & 0 & 0 & 0 \\
\hline & 0,492926906 & 0,011659775 & 1,090557644 \\
\hline
\end{tabular}

From the orange yellow L5 data analysis above it can be taken that the red Hue $(\mathrm{H})$ has a value of 0.03400204 and an orange Hue $(\mathrm{H})$ 0.045336053. Therefore, the dominating color of the orange yellow L5 is red and orange with the number 0.079338094 . So the comparison of the usual yellow L5 results above is equally yielding 0 Luminance. From the pale yellow L3 analysis above, it can be concluded that there are 2 dominating values, namely Hue (red) and Hue (orange) Luminance Hue (red) is 0.03400204 and Hue (orange) is 0.045336053 .

\section{CONCLUSION}

Based on the results of trials of samples of domestic chicken egg yolks with orange yellow, ordinary yellow and pale yellow, the nutritional content is produced based on the color produced containing water content, ash content, fat content, protein content, carbohydrate levels, calcium (Ca), phosphorus ( $\mathrm{P}$ ) different and $85 \%$ for the similarity of egg yolk.

\section{REFERENCES}

[1] H. Bovšková, K. Mikova and Z. Panovská. "Evaluation of egg yolk colour." Czech Journal of Food Sciences, vol. 32, no. 3, pp. 213-217, 2014

[2] J. Batoro. Omega eggs, 2008. On line at http // www.malangkab.go.id. / Articles / articles. Cfm [ac-cessed January 12, 2012].

[3] T. Acharya and A. K. Ray. Image Processing: Principles and Applications. Canada: John Wiley \& Sons, Inc, 2005.

[4] A. M. Sarhan. "Wavelet-based feature extraction for DNA microarray classification.” Artificial Intelligence Review, vol. 39, no. 3, pp. 237-249, 2013.

[5] S. Almatsier. Basic principles of nutrition. Jakarta: Gramedia Main Library, 2001.

[6] I. K. Amirullah. Nutrition Laying Chicks. Series of Mandiri Breeding. Bogor: Publisher of Satu Gunungbudi Institute, 2003.

[7] R. Azhar, D.Tuwohingide, D. Kamudi and N. Suciati. "Batik image classification using sift feature extraction, bag of features and support vector machine.” Procedia Computer Science, vol. 72, pp 24-30, 2015
[8] H. D. Belitz, W. Grosch and P.

[9] . "Food chemistry." Annual Review Biochemistry, vol. 79, pp. 655-681, 2009.

[10] B. E. Boser, I. M. Guyon and V. N. Vapnik. "A training algorithm for optimal margin classifiers." In Proceedings of the fifth annual workshop on Computational learning theory. pp. 144-152, 1992.

[11] H. Bovšková, K. Míková and Z. Panovská. Czech Journal of Food Sciences, vol.32, no. 3, pp.213-217, 2014. Tidak ada judul

[12] T. K. Chung. "Yellow and red carotenoids for eggs yolk pigmentation." In Annual ASA Southeast Asian Feed Technology and Nutrition Workshop, 2002.

[13] D. B. Rodriguez-Amaya. A guide to carotenoid analysis in foods. Washington: ILSI press, 2001.

[14] D. U. N. I. Sari, B. Hidayat and S. Darana. "Deteksi Kesegaran Dan Kualitas Telur Berdasarkan Metode Color Matching Dan Template Matching.” eProceedings of Engineering, vol. 3, no. 2, pp. 1963-1970, 2016.

[15] D. D. A. Bakhtra, Rusdi and A. Mardiah, "Penetapan Kadar Protein Dalam Telur Unggas Melalui Analisis Nitrogen Menggunakan Metode Kjeldahl.” Jurnal Farmasi Higea, vol. 8, no. 2, pp. 143-150, 2016.

[16] E. T. Luthfi. "Fuzzy C-Means untuk Clustering Data (studi kasus data performance mengajar dosen)." In Seminar Nasional Teknologi, pp. 1-7, 2007.

[17] M. A. French, K. Sundram and M. T. Clandinin. "Cholesterolaemic effect of palmitic acid in relation to other dietary fatty acids." Asia Pacific journal of clinical nutrition, vol. 11, pp. S401-S407, 2002.

[18] P. Gaspar, J. Carbonell and J. L. Oliveira. "On the parameter optimization of Support Vector Machines for binary classification.” Journal of integrative bioinformatics, vol. 9, no. 3, pp. 33-43, 2012.

[19] G. A. Pradipta and P. D. W. Ayu. "Perbandingan segmentasi citra telur ayam menggunakan metode otsu berdasarkan perbedaan ruang warna RGB dan HSV." Jurnal Sains dan Teknologi, vol. 6, no. $1,2017$.

[20] G. Meirinda, B. Hidayat and S. Darana. "Deteksi Kualitas Dan Kesegaran Telur Ayam Negeri Berdasarkan Segmentasi Warna Menggunakan Metode Fuzzy Color Histogram (fch) Dan Histogram Equalization Dengan Klasifikasi K-nearest Neighbor (k-nn) Pada Citra Digital." eProceedings of Engineering, vol. 3, no. 2, pp. 1603-1610, 2016

[21] R. C. Gonzalez and R. E. Woods. Digital Image Processing, New Jersey: Prentice Hall, 2002.

[22] F. Gorunescu. Data Mining : Concept, Model, Techniquies, Berlin: Springer- Verlag, 2011.

[23] M. Hofman. Support Vector Machines-Kernel and the Kernel Trick. Houptseminar report, 2006

[24] C-W. Hsu, C-C. Chang and C-J. Lin, A Practice Guide to Support Vector Classification, Departement of Computer Science, National Taiwan University, 2010.

[25] I. Bifawaidati, Penerapan Algoritma Fuzzy C-Means Untuk Klasifikasi Citra Tenun Berdasarkan Fitur Tekstur. Doctoral dissertation, Institut Teknologi Sepuluh Nopember, 2017. 